\title{
Lymphatic Filariasis
}

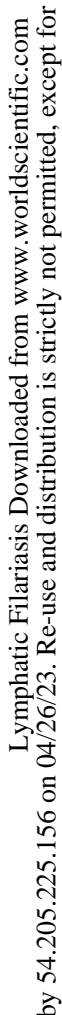


Tropical Medicine: Science and Practice

Series Editors: Geoffrey Pasvol

Dept. of Infection \& Tropical Medicine

Imperial College School of Medicine, UK

Stephen L. Hoffman

Naval Medical Research Institute

Rockville, Maryland, USA

Forthcoming

Amebiasis

Edited by J. I. Ravdin

Schistosomiasis

Edited by A. Mahmoud 


\section{TROPICAL MEDICINE \\ Science and Practice \\ Volume 1}

\section{Lymphatic Filariasis}

edited by

Thomas B. Nutman

Laboratory of Parasitic Diseases

National Institutes of Health

Bethesda, Maryland, USA

Series editors

G. Pasvol and S. L. Hoffman 
Published by

Imperial College Press

57 Shelton Street

Covent Garden

London WC2H 9HE

Distributed by

World Scientific Publishing Co. Pte. Ltd.

P O Box 128, Farrer Road, Singapore 912805

USA office: Suite 1B, 1060 Main Street, River Edge, NJ 07661

UK office: 57 Shelton Street, Covent Garden, London WC2H 9HE

\section{British Library Cataloguing-in-Publication Data}

A catalogue record for this book is available from the British Library.

\section{LYMPHATIC FILARIASIS}

Copyright $\odot 2000$ by Imperial College Press

All rights reserved. This book, or parts thereof, may not be reproduced in any form or by any means, electronic or mechanical, including photocopying, recording or any information storage and retrieval system now known or to be invented, without written permission from the Publisher.

For photocopying of material in this volume, please pay a copying fee through the Copyright Clearance Center, Inc., 222 Rosewood Drive, Danvers, MA 01923, USA. In this case permission to photocopy is not required from the publisher.

ISBN $\quad 1-86094-059-5$

Printed in Singapore by Uto-Print 


\section{Preface}

The dramatic advances made in the approach to the diagnosis and treatment of the lymphatic filariases, in our understanding of the molecular nature of the parasites that cause the diseases, and in the pathogenetic and epidemiological principles that underlie them, has allowed us to contemplate methods of control that may eliminate lymphatic filariasis as a public health concern early in the next millennium. Indeed, the past two decades have witnessed a tremendous shift in emphasis in the study of lymphatic filarial infections away from a singular view of pathogenesis and towards one that has integrated the tools of modern epidemiology, immunology, infectious diseases, molecular biology, and, perhaps most importantly, fieldbased clinical studies.

With the relative ease of international travel and the marked population shifts, filarial infections are no longer solely the domain of those living near or in the tropics. The recognition of these 'shrinking' geographical boundaries has likely provided the impetus for the present series dedicated to the understanding of tropical diseases. This volume, thus, examines the basic biology and clinical expression of the lymphatic-dwelling filarial parasites and aims to detail the underlying pathogenetic mechanisms of infection along with the epidemiology, diagnosis, treatment and prevention of these often devastating vector-borne diseases. Drawing from the collective experience of the authors, an experience that spans six continents and untold numbers of years, this volume is intended to provide a comprehensive examination of human lymphatic filariasis with emphasis not only on that which is known but also on that which remains the subject of controversy.

I am grateful for the invitation extended to my colleagues and me by the series' editors Drs. Geoffrey Pasvol and Stephen Hoffman and for the production support provided by Imperial College Press. I would very much like to thank Drs. Franklin Neva and Eric Ottesen who, each in his 
own way and style, provided me with an environment at the National Institutes of Health that allowed for scientific growth and the acquisition of clinical skills in tropical medicine. I would also like to acknowledge the many colleagues and friends who have shared their knowledge with me and have made the study of filarial infections incredibly collegial. Finally, I would most like to thank the members of my family - Alex and Sarah Nutman, and Ruth Karron - who, despite the inevitable sacrifices of personal time, supported me in my endeavor to edit this book.

Thomas B. Nutman, M.D. April 1999 


\section{Contents}

Preface v v

Chapter 1. Lymphatic Filariasis: A Historical Perspective 1

T.V. Rajan

Chapter 2. Lymphatic-dwelling Filariae

Alan L. Scott

Chapter 3. The Population Dynamics and Epidemiology of

Lymphatic Filariasis

Edwin Michael

Chapter 4. Resistance to Infection with Lymphatic-dwelling

Filarial Parasites

James W. Kazura

Chapter 5. The Clinical Manifestations of Lymphatic Filariasis

V. Kumaraswami

Chapter 6. Diagnosis of Lymphatic Filarial Infections

James McCarthy

Chapter 7. Treatment of Lymphatic Filariasis

David G. Addiss and Gerusa Dreyer

Chapter 8. Towards Eliminating Lymphatic Filariasis 
viii Lymphatic Filariasis

Chapter 9. Immunology of Lymphatic Filariasis:

Current Controversies

Rick M. Maizels, Judith E. Allen and

Maria Yazdanbakhsh

Chapter 10. Worms and Microorganisms Can Cause

Lymphatic Disease in Residents of

Filariasis-endemic Areas

Gerusa Dreyer and Willy F. Piessens

Index 